\title{
ISOLASI SENYAWA AKTIF DARI FRAKSI ETIL ASETAT DAUN Goniothalamus Macrophyllus
}

\author{
Viriyanata Wijaya $^{1, *}$, Supriyatna $^{2}$, Tiana Milanda ${ }^{2}$ \\ ${ }^{1}$ Fakultas Farmasi Universitas Mulawarman \\ ${ }^{2}$ Fakultas Farmasi Universitas Padjadjaran \\ *email: viriya_wijaya@yahoo.com
}

\begin{abstract}
ABSTRAK
Infeksi kulit pada suku dayak Punan diakibatkan kontak langsung dengan alam. Satu bakteri yang paling sering menjadi penyebab infeksi kulit di komunitas yang kurang higienis tersebut yaitu Staphylococcus aureus. Tumbuhan tendani (Goniothalamus macrophyllus) secara empiris digunakan sebagai obat luar untuk infeksi tersebut. Penelitian ini bertujuan untuk mengetahui senyawa aktif antibakteri yang terkandung dalam isolat dari fraksi etil asetat Daun G. macrophyllus. Ekstrak etanol Daun $G$. macrophyllus difraksinasi dengan n-heksan dan etil asetat. Fraksi etil asetat adalah fraksi teraktif yang menunjukkan diameter hambat sebesar $19,50 \mathrm{~mm}$ dan $22,30 \mathrm{~mm}$ untuk masing-masing konsentrasi $20 \%$ dan $30 \%$. Proses pemisahan dan pemurnian menggunakan kromatografi kolom dan kromatografi lapis tipis preparatif. Isolat diidentifikasi dengan spektoskopi, dilakukan dengan UV-vis, IR, dan MS memberikan $\lambda$ maks 202,9 nm, gugus fungsi $\mathrm{O}-\mathrm{H}, \mathrm{C}-\mathrm{H}$ alifatis, $\mathrm{C}=\mathrm{C}$ aromatis, $\mathrm{C}=\mathrm{O}$ dan $\mathrm{C}-\mathrm{H}$ aromatis, dan $\mathrm{m} / \mathrm{z} 352,9806$. Maka, senyawa aktif disimpulkan sebagai dimetoksi glabranin $\left(\mathrm{C}_{22} \mathrm{H}_{24} \mathrm{O}_{4}\right)$.
\end{abstract}

Kata kunci : Goniothalamus macrophyllus, aktivitas antibakteri, Staphylococcus aureus, isolat, senyawa aktif

\section{Pendahuluan}

Suku Dayak Punan merupakan satu kelompok suku Dayak yang tersebar di beberapa bagian pulau Kalimantan, seperti Kalimantan Timur, Kalimantan Utara (Sarawak), dan Kalimantan Barat (Hermas, 2006). Pengetahuan tentang tumbuhan obat bagi suku ini telah berkembang secara turun temurun. Yusuf (2005) melaporkan bahwa suku Dayak Punan menggunakan berbagai tumbuhan dalam pengobatan tradisional mereka, diantaranya bakung air (Hanguana malayana, Zingiberaceae), bedur (Curculigo capitulata, Amarilydaceae), galoba utan (Costus speciosus, Zingiberaceae), lempuyangan (Globba marantina, Zingiberaceae), mali (Homalomena cf. aromatica, Araceae), puar (Hornstedtia sp., Zingiberaceae), dan tendani (Goniothalamus macrophyllus, Annonaceae).

Berdasarkan laporan dari penduduk di Kecamatan Babulu Darat, masyarakat suku Dayak Punan di daerah tersebut menggunakan daun tendani (G. macrophyllus) untuk mengobati infeksi kulit, yang disebabkan kontak langsung dengan alam atau kondisi yang kurang higienis, sedangkan bagian akarnya digunakan sebagai obat demam (Yusuf, 2005). Secara empiris, sehelai atau dua helai daun ditempelkan atau digosokkan pada kulit yang terkena infeksi dan gatal (Yusuf, 2005).

S. aureus dikenal sebagai bakteri penyebab berbagai penyakit infeksi pada kulit. Bakteri ini mampu melekat pada plasma darah dan protein pengangkut matriks ekstraselular pada materi biologis. Beberapa organel pelekatan spesifik pada permukaan sel $S$. aureus dapat berinteraksi dengan sejumlah protein, seperti fibronektin, fibrinogen, kolagen, vitronektin, dan laminin (Foster and Mc Devitt, 1994). S. aureus lebih virulen 
dibanding bakeri lainnya dari genus yang sama dan resisten terhadap berbagai antibiotik (Waldvogel, 1990; Projan and Novick, 1997; Lowy, 1998).

Sampai saat ini belum ada informasi ilmiah tentang aktivitas antibakteri dari ekstrak, fraksi, dan isolat daun G. macrophyllus terhadap S. aureus, sehingga penelitian tentang karakterisasi senyawa aktifnya perlu untuk dilakukan.

\section{Alat dan Bahan}

Alat-alat yang digunakan dalam penelitian ini adalah maserator, desikator vakum, rotary evaporator (Buchi Rotavapor, R-300), water bath (Memmert), pelat silika gel GF 254, silika gel 60 GF 254 (Merck), silka gel 60 kromatografi kolom (Merck), lampu UV $254 \mathrm{~nm}$ dan $366 \mathrm{~nm}$ (Camag), spektrofotometer uv-vis (Shimadzu, 1800), Fourier Transform IR Spectroscopy (Shimadzu, IR-Tracer 100), ES-TOF Mass Spectrometer (Shimadzu, 6200), hot plate (Toyomi, HP 115F1), inkubator (Sakura, IF-4), jangka sorong (Vernier Calipers), jarum ose, laminar air flow (Minihelic), mikropipet 10-100 $\mu 1$ (Biohit Proline), tip mikropipet ukuran 10-100 $\mu \mathrm{L}$ (Eppendorff), microplate (Biohit Proline), otoklaf (Hirayama, IA-1000), oven (Memmert 200 dan Memmert 400-800), pembakar spiritus, timbangan analitik (Mettler Toledo, AL204) dan alat-alat gelas yang umum dipakai di Laboratorium Farmakognosi-Fitokimia dan Laboratorium Mikrobiologi Farmasi, Fakultas Farmasi, Universitas Padjadjaran.

Bahan tumbuhan yang digunakan dalam penelitian ini adalah daun tendani yang berasal dari kawasan hutan Sungai Baru di Kecamatan Babulu Darat, Kabupaten Penajam Pasir Utara, Kalimantan Timur.

Bahan kimia yang digunakan adalah etanol 70\% (PT. Dover Chem), n-heksan (PT. Dover Chem), etil asetat (PT. Dover Chem), metanol (PT. Dover Chem), amonia (Merck), kloroform (PT. Quadrant), asam klorida (Merck), eter (Merck), natrium hidroksida (Merck), DMSO/dimetilsulfooksida (Merck), serbuk magnesium (PT. Dover Chem), pereaksi Mayer, pereaksi Dragendorf, pereaksi besi (III) klorida, pereaksi LiebermannBurchard, suspensi Mc. Farland 0,5 $(9,5 \mathrm{~mL}$ asam sulfat $1 \% \mathrm{~b} / \mathrm{v}$ dan 0,5 mL barium klorida $1 \% \mathrm{v} / \mathrm{v}$ ) dan air suling.

Biakan bakteri yang digunakan adalah S. aureus ATCC 25923 yang berasal dari PT. Biofarma. Bandung. Medium pertumbuhan atau medium uji yang digunakan adalah NA/Nutrient Agar (Oxoid, Basingstoke, UK) dan NB/Nutrient Broth (Oxoid, Basingstoke, $\mathrm{UK})$.

\section{Metode}

\section{Fraksinasi Ekstrak}

Sebanyak 50 g ekstrak etanol daun tendani difraksinasi dengan pelarut n-heksan, etil asetat, dan air masing-masing sebanyak $300 \mathrm{~mL}$ pada corong pisah. Fraksinasi dilakukan dengan menambahkan pelarut n-heksan dan etil asetat secara berturut-turut. Hasil fraksinasi dipanaskan di atas waterbath sampai diperoleh fraksi n-heksan, fraksi etil asetat dan fraksi air pekat. Fraksi-fraksi tersebut diamati warna dan bentuk kemudian dihitung rendemennya.

\section{Uji Aktivitas Antibakteri Ekstrak dan Berbagai Fraksi}

Masing-masing fraksi n-heksan, fraksi etil asetat, dan fraksi air pada konsentrasi $20 \%$ dan 30\%; dan konsentrasi ekstrak 20\% dimasukkan ke dalam lubang-lubang pencadang. Cawan-cawan petri uji diinkubasi pada suhu $37^{\circ} \mathrm{C}$ selama $18-24$ jam. Diameter zona hambat di sekitar lubang pencadang diukur menggunakan jangka sorong. Aktivitas antibakteri berbagai fraksi dibandingkan dengan aktivitas antibakteri ekstraknya, lalu ditentukan fraksi teraktif. 


\section{Pemisahan Subfraksi dari Fraksi Teraktif Menggunakan Kromatografi Kolom dan Kromatografi Lapis Tipis}

Fraksi etil asetat yang diperoleh dipantau pola bercaknya terlebih dahulu dengan eluen $4 \mathrm{~mL}$ etil asetat 100\% di bawah sinar UV $254 \mathrm{~nm}$ dan $366 \mathrm{~nm}$. Dilihat pola bercak dan dihitung Rfnya sebelum dilanjutkan ke tahap isolasi dengan kromatografi kolom.

Subfraksi dari fraksi teraktif dipisahkan menggunakan kromatografi kolom dua tahap. Pada tahap pertama, sebanyak $3 \mathrm{~g}$ fraksi teraktif ditimbang dan dilarutkan dalam 5 $\mathrm{mL}$ aseton, dicampurkan dengan silika gel kolom (1: 1) dengan ukuran mesh 70-230, kemudian dikeringkan di udara terbuka.

Sebanyak 30 g silika gel kolom (silika G60) direndam dalam n-heksan hingga batas atas silika, lalu dipadatkan ke dalam kolom. Sampel hasil impreg dimasukkan ke dalam kolom, lalu dielusi dengan eluen dengan gradien kepolaran berbeda. Eluen yang digunakan adalah $100 \mathrm{~mL}$ n-heksan: etil asetat dengan 7 perbandingan yaitu $100: 0,90$ : $10,80: 20,70: 30,60: 40,50: 50$, dan $40: 60$. Masing-masing subfraksi ditampung sampai volume $100 \mathrm{~mL}$ dalam botol $140 \mathrm{~mL}$. Seluruh subfraksi dipantau pola bercak menggunakan KLT silika $\mathrm{GF}_{254}$, dengan eluen n-heksan : etil asetat (5:5), lalu dihitung Rfnya. Subfraksi yang mempunyai pola bercak dan Rf yang sama digabungkan. Seluruh subfraksi diamati bau, warna, dan bentuknya, lalu dihitung rendemennya.

Sebanyak 0,5 g fraksi kolom pertama dielusi menggunakan kromatografi kolom tahap kedua secara isokratik menggunakan $100 \mathrm{~mL}$ eluen n-heksan : etil asetat (6:4). Silika gel yang digunakan adalah silika G60 dengan ukuran mesh 200-400. Sebanyak 20 subfraksi ditampung sampai volume masing-masing sebesar $5 \mathrm{~mL}$ dalam vial. Fraksi kolom pertama dipantau pola bercak menggunakan pelat KLT silika $\mathrm{GF}_{254}$, lalu dihitung Rfnya. Seluruh subfraksi diamati warna, dan bentuknya, lalu dikeringkan dan ditimbang untuk dihitung rendemennya.

\section{Pemisahan dan Pemurnian Isolat Teraktif Menggunakan Kromatografi Lapis Tipis Preparatif}

Sampel yang digunakan untuk Kromatografi Lapis Tipis (KLT) preparatif adalah subfraksi yang diduga mempunyai aktivitas antibakteri. Pelat KLT disiapkan dengan tahapan cara menimbang $50 \mathrm{~g}$ silika gel GF 254, dilarutkan dengan $100 \mathrm{~mL}$ air suling, lalu dihomogenkan dengan cara dikocok. Campuran dimasukkan ke dalam cetakan pelat, di atas pelat kaca berukuran $20 \mathrm{~cm} \times 20 \mathrm{~cm}$, dan dibiarkan sampai mengering di udara terbuka. Pelat dimasukkan ke dalam oven bersuhu $120^{\circ} \mathrm{C}$ selama $1-2$ jam untuk mengaktifkannya.

KLT preparatif dilakukan sebanyak 2 tahap. Pada tahap pertama, sebanyak 0,0486 g subfraksi dilarutkan dalam $5 \mathrm{~mL}$ aseton, lalu ditotolkan menggunakan pipa kapiler, dengan jarak sekitar satu $\mathrm{cm}$ dari ujung pelat KLT preparatif. Pelat KLT dimasukkan ke dalam wadah kromatografi yang telah dijenuhkan dengan n-heksan:etil asetat (1:1). Eluen dibiarkan merambat mencapai batas atas pelat yang telah ditandai. Pelat KLT diangkat dan dibiarkan mengering pada udara terbuka. Pita noda diamati di bawah sinar tampak, sinar UV $254 \mathrm{~nm}$, dan sinar UV $366 \mathrm{~nm}$. Bentuk pita diberi tanda, diberi kaca, kemudian dikerok. Hasil kerokan dilarutkan dalam $5 \mathrm{~mL}$ aseton dalam vial, kemudian dikeringkan. Subfraksi diamati warna dan bentuknya lalu dihitung rendemennya. Pola bercak dan Rf dari subfraksi dipantau kembali pada pelat KLT dengan eluen n-heksan:etil asetat $(9,5: 0,5)$, lalu diamati di bawah sinar UV $254 \mathrm{~nm}$ dan UV $366 \mathrm{~nm}$.

Sebanyak 0,0084 g subfraksi dilarutkan dengan $5 \mathrm{~mL}$ aseton, kemudian ditotolkan menggunakan pipa kapiler hingga membentuk pita pada KLT preparatif. KLT dielusi menggunakan eluen kloroform:n-heksan (1:1). Bentuk pita diberi tanda, diberi kaca, kemudian dikerok. Hasil kerokan dilarutkan dalam $5 \mathrm{~mL}$ aseton,lalu dikeringkan. 
Subfraksi diamati warna dan bentuknya, lalu dihitung rendemennya. Pola bercak dan Rf dari subfraksi dipantau kembali pada plat KLT dengan eluen n-heksan:etil asetat (8:2), lalu diamati di bawah sinar UV $254 \mathrm{~nm}$ dan UV $366 \mathrm{~nm}$.

\section{Pengujian Kemurnian Isolat Menggunakan Kromatografi Lapis Tipis Dua Dimensi}

Isolat diuji kemurniannya menggunakan Kromatografi Lapis Tipis (KLT) dua dimensi dengan pelat KLT berukuran $10 \times 10 \mathrm{~cm}$, menggunakan dua perbandingan eluen untuk elusi pertama dan elusi kedua. Elusi pertama menggunakan n-heksan : etil asetat $(7,5: 2,5)$. Hasil elusi diamati di bawah sinar tampak, sinar UV $254 \mathrm{~nm}$ dan UV $366 \mathrm{~nm}$. Arah elusi dibalik arah ke kanan berlawanan arah jarum jam, dimana pelat KLT dielusi menggunakan kloroform : n-heksan $(5: 5)$. Hasil elusi diamati di bawah sinar tampak, sinar UV $254 \mathrm{~nm}$ dan UV $366 \mathrm{~nm}$.

\section{Karakterisasi Senyawa Aktif Melalui Spektrofotometri UV-VIS, Spektroskopi IR, dan Spektrometri Massa}

Karakterisasi senyawa aktif dilakukan dengan menggunakan beberapa instrumen, yaitu :

\section{Karakterisasi Senyawa Aktif Menggunakan Spektrofotometri UV-Vis}

Sebanyak $0,5 \mathrm{mg}$ senyawa aktif dilarutkan dalam $0,5 \mathrm{~mL}$ metanol hingga didapat konsentrasi $1000 \mathrm{ppm}$, lalu dimasukkan dalam kuvet. Sebanyak 0,5 mL metanol digunakan sebagai blanko, lalu dimasukkan ke kuvet kedua. Kedua kuvet (blanko dan zat aktif + blanko) dan diukur \% $\mathrm{T}$ (A) pada spektrofotometer uv-vis. Larutan dalam kedua kuvet diukur serapan/absorbannya daerah sinar uv (200-400 nm) dan sinar tampak (400-750 nm) pada spektrofotometer tersebut. Dilihat pita yang muncul pada spektra UV. Absorbansi maksimum larutan yang dihasilkan dari pengukuran absorban dalam rentang panjang gelombang tersebut dicatat.

\section{Karakterisasi Senyawa Aktif Menggunakan Spektrofotometri Inframerah}

Sebanyak 0,5 mg isolat dicampur dengan $100 \mathrm{mg}$ serbuk kalium bromida. Campuran ini ditekan menggunakan alat penekan hidrolik ( $\mathrm{KBr}$ pellet die) dengan tekanan $10.000-15.000$ psi, sehingga membentuk suatu pelat bulat dan tipis dengan ketebalan 0,1 $\mathrm{mm}$. Pelat $\mathrm{KBr}$ dipasang dalam sel, lalu ditempatkan dalam jalan berkas sinar pada spektroskopi IR untuk diamati serapan yang dihasilkan pada bilangan gelombang 450$4000 \mathrm{~cm}^{-1}$. Spektrum IM pada masing-masing bilangan gelombang diamati, lalu dicocokkan dengan tabel IR dari pustaka (Wiley Library).

\section{Spektrometri Massa (MS)}

Sebanyak 0,5 mg isolat aktif dilarutkan dalam $1 \mathrm{~mL}$ aseton. Sebanyak 0,3 mikron campuran dimasukkan ke dalam chamber MS dengan bantuan mycrosyringe. Analyzer massa yang digunakan adalah TOF (Time of Flight) menggunakan medan listrik untuk meningkatkan kecepatan ion-ion melalui potensial sama dan mengukur waktu yang diperlukan untuk mencapai defaktor. Ion yang ringan akan mencapai defaktor lebih dahulu. Kondisi yang digunakan untuk menganalis sampel adalah energi elektron $70 \mathrm{ev}$, laju alir pelarut $4 \mu \mathrm{L} /$ menit, spray voltage $4 \mathrm{kV}$, laju alir gas kering 15 psi (1 bar), suhu desolvasi $180^{\circ} \mathrm{C}$, dan $\mathrm{m} / \mathrm{z}$ range $50-900$. Puncak spektrum massa diamati dari berat molekul senyawa dengan kelimpahan $100 \%$.

Ketiga spektrum UV-vis, IR, dan MS dibaca untuk menentukan panjang gelombang maksimum, gugus fungsi dan struktur molekul senyawa aktif dari isolat dari ekstrak etanol daun tendani. 


\section{Pembahasan}

\section{Hasil Fraksinasi Ekstrak}

Fraksinasi $50 \mathrm{~g}$ ekstrak daun tendani menghasilkan fraksi n-heksan sebesar 5,58 g, fraksi etil asetat sebesar 7,4 g, dan fraksi air sebesar 12,8 g. Hasil pengamatan visual dan rendemen fraksi-fraksi terhadap ekstrak terdapat pada Tabel 1.

Tabel 1. Hasil Pengamatan Visual dan Rendemen Fraksi dari Ekstrak Etanol Daun Tendani

\begin{tabular}{cllc}
\hline \multirow{2}{*}{ Fraksi } & \multicolumn{2}{c}{ Pengamatan Visual } & Rendemen \\
\cline { 2 - 3 } fraksi $(\% \mathrm{~b} / \mathrm{b})$
\end{tabular}

\section{Hasil Uji Aktivitas Antibakteri Ekstrak dan Berbagai Fraksi}

Hasil uji aktivitas antibakteri ekstrak etanol dan berbagai fraksi dari daun tendani terhadap S.aureus ATCC 25923 dapat dilihat pada Tabel 2.

Tabel 2. Hasil Uji Aktivitas Antibakteri Ekstrak Etanol dan Berbagai Fraksi Daun Tendani terhadap S. aureus ATCC 25923

\begin{tabular}{lcc}
\hline \multirow{2}{*}{ Bahan uji } & \begin{tabular}{l} 
Diameter hambat $\begin{array}{c}\text { S. Aureus } \\
\text { pada konsentrasi bahan uji }\end{array}$ \\
\cline { 2 - 3 }
\end{tabular} & ATCC 25923 (mm) \\
\hline Ekstrak 20\% & 22,0 & $30 \%(\% \mathrm{~b} / \mathrm{v})$ \\
Fraksi n-heksan & 12,9 & 22,7 \\
Fraksi etil asetat & 19,5 & 14 \\
Fraksi air & 19,1 & 22,3 \\
\hline
\end{tabular}

Keterangan : diameter lubang pencadang $8 \mathrm{~mm}$

Tabel 2 menunjukkan bahwa fraksi etil asetat pada konsentrasi 20\% dan 30\% memiliki aktivitas terbesar terhadap S. aureus ATCC 25923 dibandingkan fraksi n-heksan dan fraksi air, namun ekstrak memiliki aktivitas yang lebih besar dari zat aktifnya. Hal ini disebabkan oleh ekstrak masih merupakan campuran metabolit sekunder yang lebih banyak, sehingga aktivitas yang dihasilkan lebih maksimal.

\section{Hasil Pemisahan Subfraksi dari Fraksi Teraktif Menggunakan Kromatografi Kolom dan Kromatografi Lapis Tipis}

Fraksi etil asetat dipantau pola bercak dan Rfnya dengan eluen etil asetat $100 \%$. Hasil KLT Fraksi etil asetat dapat dijelaskan pada Tabel 3. 
Tabel 3. Hasil Kromatografi Lapis Tipis Fraksi Etil Asetat

\begin{tabular}{ccll}
\hline No & \multicolumn{3}{c}{ Rf dan warna bercak di bawah } \\
\cline { 2 - 4 } Bercak & Rf & Sinar UV 254 nm & Sinar UV 366 nm \\
\hline 1 & 0,59 & Hijau tua & Kuning muda \\
2 & 0,63 & Hijau tua & Kuning tua \\
3 & 0,75 & Hijau kehitaman & Merah tua \\
4 & 0,81 & Hijau muda & Merah keunguan \\
\hline
\end{tabular}

Dari Tabel 3 dapat diketahui bahwa senyawa aktif dalam fraksi etil asetat masih belum terpisah dengan baik pada plat KLT. Pemantauan pola KLT dari ekstrak etanol dan fraksi etil asetat daun tendani dilakukan untuk melihat perbandingan pola bercak dan jarak pemisahan yang lebih baik. Eluen etil asetat digunakan, karena merupakan pelarut semi polar sehingga pola bercak yang terlihat dapat berasal dari senyawa non polar maupun polar. Diamati di bawah lampu UV $254 \mathrm{~nm}$ dan $366 \mathrm{~nm}$, terlihat bahwa fraksi etil asetat mempunyai pola bercak yang lebih jelas dan spesifik.

Metode kromatografi kolom dipilih karena sampel yang digunakan lebih sedikit (< $30 \mathrm{~g}$ ) serta interaksi antara waktu kontak sampel, fase gerak, dan fase diam lebih lama sehingga pemisahan semakin baik. Hasil kromatografi kolom fraksi etil asetat dijelaskan pada Tabel 4.

Tabel 4. Hasil Kromatografi Kolom Fraksi Etil Asetat

\begin{tabular}{ccc}
\hline $\begin{array}{c}\text { No } \\
\text { Subraksi }\end{array}$ & Eluen & Warna eluat \\
\hline SF 1 & n-heksan 100\% & Bening \\
SF 2 & n-heksan : etil asetat $(90: 10)$ & Bening \\
SF 3 & n-heksan : etil asetat $(80: 20)$ & Kuning pucat \\
SF 4 & n-heksan : etil asetat $(70: 30)$ & Kuning tua \\
SF 5 & n-heksan : etil asetat $(60: 40)$ & Kuning tua \\
SF 6 & n-heksan : etil asetat $(50: 50)$ & Kuning coklat \\
SF 7 & n-heksan : etil asetat $(40: 60)$ & Kuning coklat \\
\hline
\end{tabular}

Dari Tabel 4, diketahui terdapat 7 sub fraksi besar dari fraksi kolom yaitu subfraksi 1, subfraksi 2, subfraksi 3, dan subfraksi 4-7. Subfraksi 4-7 merupakan hasil penggabungan dari subfraksi 4 hingga 7 , yang berdasarkan pemantauan pola bercak dan Rf dari KLT dengan menggunakan perbandingan eluen n-heksan : etil asetat (5:5).

Fraksi etil asetat sebesar $3 \mathrm{~g}$ difraksinasi untuk memisahkan senyawa-senyawanya menggunakan kromatografi kolom terbuka/gravitasi dengan elusi sistem gradien kepolaran. Pelarut yang digunakan yaitu n-heksan dan etil asetat dengan gradien $10 \%$. Pemilihan fase gerak berdasarkan perbandingan kepolaran yang umum digunakan dalam kromatografi kolom secara gradien.

Hasil pengamatan visual masing-masing subfraksi berupa serbuk putih dan hitungan rendemen subfraksi dapat dilihat pada Tabel 5. 
Tabel 5. Rendemen Subfraksi Kolom Pertama

\begin{tabular}{ccc}
\hline Nama subfraksi & Berat $(\mathrm{g})$ & Rendemen $(\% \mathrm{~b} / \mathrm{b})$ \\
\hline Subfraksi 1 & $156,1 \mathrm{mg}$ & $5,20 \%$ \\
Subfraksi 2 & $178,2 \mathrm{mg}$ & $5,94 \%$ \\
Subfraksi 3 & $192,9 \mathrm{mg}$ & $6,43 \%$ \\
Subfraksi 4-7 & $792,1 \mathrm{mg}$ & $26,40 \%$ \\
\hline
\end{tabular}

Hasil kromatografi lapis tipis dari subfraksi Kolom Pertama dapat dijelaskan pada Tabel 5.

Tabel 5. Hasil Kromatografi Lapis Tipis Subfraksi Kolom Pertama

\begin{tabular}{|c|c|c|c|c|}
\hline $\begin{array}{c}\text { Nama } \\
\text { Subfraksi }\end{array}$ & No bercak & $\mathrm{Rf}$ & $\begin{array}{c}\text { Warna } \\
\text { sinar tampak }\end{array}$ & $\begin{array}{c}\text { Warna } \\
\text { sinar UV } 366 \mathrm{~nm}\end{array}$ \\
\hline SF 1 & 1 & 0,90 & Kuning tua & Flouresensi biru tua \\
\hline \multirow[t]{2}{*}{ SF 2} & 1 & 0,70 & - & Kuning tua \\
\hline & 2 & 0,90 & Kuning tua & Fluoresensi biru tua \\
\hline \multirow[t]{3}{*}{ SF 3} & 1 & 0,48 & Hitam & Merah keunguan \\
\hline & 2 & 0,70 & - & Merah tua \\
\hline & 3 & 0,90 & Kuning tua & Flouresensi biru tua \\
\hline \multirow[t]{4}{*}{ SF 4} & 1 & 0,30 & Kuning tua & Kuning muda \\
\hline & 2 & 0,48 & Hitam & Merah keunguan \\
\hline & 3 & 0,70 & - & Merah tua \\
\hline & 4 & 0,90 & Kuning tua & Fluoresensi biru tua \\
\hline \multirow[t]{4}{*}{ SF 5} & 1 & 0,30 & Kuning tua & Kuning muda \\
\hline & 2 & 0,48 & Hitam & Merah keunguan \\
\hline & 3 & 0,70 & - & Merah tua \\
\hline & 4 & 0,90 & Kuning muda & Fluoresensi biru tua \\
\hline \multirow[t]{4}{*}{ SF 6} & 1 & 0,30 & Kuning tua & Kuning muda \\
\hline & 2 & 0,48 & Hitam & Merah keunguan \\
\hline & 3 & 0,70 & - & Merah tua \\
\hline & 4 & 0,90 & Kuning muda & Fluoresensi biru tua \\
\hline \multirow[t]{4}{*}{ SF 7} & 1 & 0,30 & Kuning tua & Kuning muda \\
\hline & 2 & 0,48 & Hitam & Merah keunguan \\
\hline & 3 & 0,70 & - & Merah tua \\
\hline & 4 & 0,90 & Kuning muda & Fluoresensi biru tua \\
\hline
\end{tabular}

Subfraksi 4-7 (SF IV) dipisahkan kembali dengan kromatografi kolom terbuka secara isokratik dengan eluen etil asetat : n-heksan (4:6). Pemilihan fase gerak pada kromatografi kolom yang kedua diperoleh melalui pemantauan pola bercak KLT terhadap subfraksi I menggunakan pengembang n-heksan : etil asetat dengan perbandingan bervariasi.

Dari kromatografi kolom yang kedua diperoleh 20 subfraksi. Berdasarkan pengamatan visual, masing-masing subfraksi berbentuk serbuk putih. Fraksi-fraksi ini dipantau pola bercaknya dengan kromatografi lapis tipis. Berdasarkan pola bercak KLT menggunakan eluen etil asetat : n-heksan (4:6), dilakukan penggabungan beberapa fraksi, sehingga diperoleh 4 gabungan fraksi, yaitu SF IV.1-9 tidak menghasilkan bercak, SF 
IV.10-11 (SF IVA), SF IV.12-17 (SF IVB), dan SF IV. 18-20 (SF IVC). Rendemen subfraksi dijelaskan pada Tabel 6.

Tabel 6. Rendemen Subfraksi Kolom Kedua terhadap Subfraksi Kolom Pertama

\begin{tabular}{lll}
\hline Nama subfraksi & Berat $(\mathrm{g})$ & Rendemen $(\%)$ \\
\hline SF IV.10-11 & $10,2 \mathrm{mg}$ & $1,29 \%$ \\
SF IV.12-17 & $48,6 \mathrm{mg}$ & $6,13 \%$ \\
SF IV.18-20 & $16,5 \mathrm{mg}$ & $2,08 \%$ \\
\hline
\end{tabular}

Hasil Kromatografi Lapis Tipis kolom kedua dapat dilihat pada Tabel 7.

Tabel 7. Hasil Kromatografi Lapis Tipis Subfraksi Kolom Kedua

\begin{tabular}{|c|c|c|c|c|}
\hline $\begin{array}{l}\text { Nama } \\
\text { fraksi }\end{array}$ & No bercak & Rf & $\begin{array}{l}\text { Warna di bawah } \\
\text { sinar UV } 254 \mathrm{~nm}\end{array}$ & $\begin{array}{l}\text { Warna di bawah } \\
\text { sinar UV } 366 \mathrm{~nm}\end{array}$ \\
\hline \multirow[t]{2}{*}{ SF IV.10 } & 1 & 0,47 & Hitam & Hijau tua \\
\hline & 2 & 0,67 & Hitam & Fluoresensi biru \\
\hline \multirow[t]{3}{*}{ SF IV.11 } & 1 & 0,47 & Hitam & Hijau tua \\
\hline & 2 & 0,53 & Hitam & Merah tua \\
\hline & 3 & 0,67 & Hitam & Fluoresensi biru \\
\hline \multirow[t]{5}{*}{ SF IV.12 } & 1 & 0,06 & Hitam & Biru tua \\
\hline & 2 & 0,38 & Hitam & Merah keunguan \\
\hline & 3 & 0,47 & Hitam & Merah muda \\
\hline & 4 & 0,53 & Hitam & Merah tua \\
\hline & 5 & 0,67 & Hitam & Fluoresensi biru \\
\hline \multirow[t]{5}{*}{ SF IV.13 } & 1 & 0,06 & Hitam & Biru tua \\
\hline & 2 & 0,38 & Hitam & Merah keunguan \\
\hline & 3 & 0,47 & Hitam & Merah muda \\
\hline & 4 & 0,53 & Hitam & Merah tua \\
\hline & 5 & 0,67 & Hitam & Fluoresensi biru \\
\hline \multirow[t]{5}{*}{ SF IV.14 } & 1 & 0,06 & Hitam & Biru tua \\
\hline & 2 & 0,38 & Hitam & Merah keunguan \\
\hline & 3 & 0,47 & Hitam & Merah muda \\
\hline & 4 & 0,53 & Hitam & Merah tua \\
\hline & 5 & 0,67 & Hitam & Fluoresensi biru \\
\hline \multirow[t]{5}{*}{ SF IV.15 } & 1 & 0,06 & Hitam & Biru tua \\
\hline & 2 & 0,38 & Hitam & Merah keunguan \\
\hline & 3 & 0,47 & Hitam & Merah muda \\
\hline & 4 & 0,53 & Hitam & Merah tua \\
\hline & 5 & 0,67 & Hitam & Fluoresensi biru \\
\hline \multirow[t]{5}{*}{ SF IV.16 } & 1 & 0,06 & Hitam & Biru tua \\
\hline & 2 & 0,38 & Hitam & Merah keunguan \\
\hline & 3 & 0,47 & Hitam & Merah muda \\
\hline & 4 & 0,53 & Hitam & Merah tua \\
\hline & 5 & 0,67 & Hitam & Fluoresensi biru \\
\hline SF IV.17 & 1 & 0,06 & Hitam & Biru tua \\
\hline
\end{tabular}




\begin{tabular}{lllll}
\hline & 2 & 0,38 & Hitam & Merah keunguan \\
& 3 & 0,47 & Hitam & Merah muda \\
& 4 & 0,53 & Hitam & Merah tua \\
& 5 & 0,67 & Hitam & Fluoresensi biru \\
\hline SF IV.18 & 1 & 0,21 & Hitam & Merah keunguan \\
& 2 & 0,28 & Hitam & Merah tua \\
& 3 & 0,38 & Hitam & Merah tua \\
\hline SF IV.19 & 1 & 0,21 & Hitam & Merah keunguan \\
& 2 & 0,28 & Hitam & Merah tua \\
& 3 & 0,38 & Hitam & Merah tua \\
\hline SF IV.20 & 1 & 0,21 & Hitam & Merah keunguan \\
& 2 & 0,28 & Hitam & Merah tua \\
& 3 & 0,38 & Hitam & Merah tua \\
\hline
\end{tabular}

Berdasarkan hasil kromatografi lapis tipis, diambil sub fraksi SFIVB dengan jumlah pola bercak yang spesifik kemudian dikeringkan dan ditimbang. Berat subfraksi SF IVB sebesar 48,6 mg, lalu dipisahkan kembali dengan kromatografi lapis tipis preparatif.

\section{Hasil Pemisahan dan Pemurnian Isolat Teraktif Menggunakan Kromatografi Lapis Tipis Preparatif}

KLT preparatif dipilih karena lebih mudah dilakukan, pola pemisahan lebih mudah diamati, serta mempercepat pemisahan dengan waktu yang lebih efisien. SF IVB dilakukan pemisahan dengan KLT preparatif. Dari hasil KLT preparatif, diperoleh 4 pita utama. Hasil KLT preparatif dapat dijelaskan pada Tabel 7.

Tabel 7. Hasil Kromatografi Lapis Tipis Preparatif SF IVB

\begin{tabular}{ccll}
\hline \multirow{2}{*}{ No. Pita } & \multicolumn{3}{c}{ Rf dan warna bercak di bawah } \\
\cline { 2 - 4 } & Rf & Sinar tampak & Sinar UV 366 nm \\
\hline 1 & 0,33 & Kuning tua & Merah tua \\
2 & 0,44 & Hijau muda & Biru muda \\
3 & 0,55 & Hitam & Biru muda \\
4 & 0,67 & Kuning muda & Fluoresensi biru \\
\hline
\end{tabular}

Masing-masing pita (pita 1-4) dikerok, lalu dilarutkan dengan $5 \mathrm{~mL}$ aseton $100 \%$. Secara organoleptik, SF IV $B_{1}$ (no. bercak ke-4), SF IV $B_{2}$ (no.bercak ke-3), SF IV $B_{3}$ (no.bercak ke-2), dan SF IV $\mathrm{B}_{4}$ (no. bercak ke-1). Masing-masing subfraksi kemudian diuapkan hingga diperoleh subfraksi kering dan ditimbang. Berdasarkan pengamatan visual, masing-masing subfraksi berbentuk serbuk putih dan rendemen subfraksi terdapat pada Tabel 8.

Tabel 8. Rendemen Subfraksi KLT Preparatif Pertama Terhadap Subfraksi Kolom Kedua

\begin{tabular}{lll}
\hline Nama subfraksi & Berat $(\mathrm{g})$ & Rendemen $(\% \mathrm{~b} / \mathrm{b})$ \\
\hline SF IV B & $8,4 \mathrm{mg}$ & $17,2 \%$ \\
SF IV B & $11,85 \mathrm{mg}$ & $24,38 \%$ \\
SF IV B & $14,7 \mathrm{mg}$ & $30,25 \%$ \\
SF IV B & $16,3 \mathrm{mg}$ & $33,54 \%$ \\
\hline
\end{tabular}


Keempat subfraksi dilakukan pemantauan kembali pola bercak KLT untuk memastikan pemisahannya. Fase gerak yang digunakan adalah n-heksan : etil asetat $(9,5$ : 0,5). Setelah diamati di bawah lampu UV $254 \mathrm{~nm}$ dan $366 \mathrm{~nm}$, disemprotkan $\mathrm{H}_{2} \mathrm{SO}_{4}$ pekat sebagai pendeteksi bercak sehingga bercak noda tampak lebih jelas terlihat. Hasil kromatografi lapis tipis dijelaskan pada Tabel 9.

Tabel 9. Hasil Kromatografi Lapis Tipis SF IVB

\begin{tabular}{cccll}
\hline & & & \multicolumn{2}{c}{ Warna di bawah } \\
\cline { 4 - 5 } $\begin{array}{c}\text { Nama } \\
\text { fraksi }\end{array}$ & No bercak & Rf & & $\begin{array}{c}\text { Sinar UV 366 nm } \\
\text { dengan pendeteksi } \\
\text { bercak } \mathrm{H}_{2} \mathrm{SO}_{4} \text { pekat }\end{array}$ \\
\hline SF IV B B $_{1}$ & 1 & 0,12 & Hijau muda & $\begin{array}{l}\text { Hijau muda } \\
\end{array}$ \\
& 2 & 0,17 & Hijau terang & Hijau tua \\
& 3 & 0,22 & Biru tua & Biru terang \\
\hline SF IV B & 1 & 0,12 & Jingga & Jingga \\
& 2 & 0,17 & Hijau terang & Hijau terang \\
& 3 & 0,22 & Biru tua & Biru tua \\
\hline SF IV B & 1 & 0,12 & Merah tua & Merah tua \\
& 2 & 0,17 & Biru tua & Biru tua \\
& 3 & 0,22 & - & - \\
\hline SF IV B & 1 & 0,12 & Jingga & Kuning \\
& 2 & 0,17 & Hijau muda & Hijau terang \\
& 3 & 0,22 & - & Biru muda \\
\hline
\end{tabular}

Dari pemantauan pola bercak plat KLT, SF IV $\mathrm{B}_{1}$ memiliki pola bercak yang dominan dan spesifik, sehingga dilakukan KLT preparatif lanjutan dengan menggunakan eluen kloroform : n-heksan (1:1). Pemilihan eluen berdasarkan hasil optimasi pola bercak pada KLT preparatif sebelumnya, pemisahan yang lebih baik, dan penurunan kepolaran agar pola bercak yang dihasilkan dalam Rf yang tidak terlalu jauh dari area penotolan dan lebih jelas terlihat. Hasil Kromatografi Lapis Tipis Preparatif Lanjutan dijelaskan pada Tabel 10.

Tabel 10. Hasil Kromatografi Lapis Tipis Preparatif SF IV B

\begin{tabular}{ccccc}
\hline & \multicolumn{3}{c}{ Rf dan Warna dengan Pendeteksi } \\
\cline { 2 - 5 } No & Rf & $\begin{array}{c}\text { Sinar UV } \lambda 254 \\
\text { mm }\end{array}$ & \multicolumn{2}{c}{$\begin{array}{c}\text { Sinar UV } \lambda 366 \\
\text { nm }\end{array}$} \\
\hline 1 & 0,38 & - & Biru muda & Biru muda \\
\hline 2 & 0,4 & Biru tua & $\begin{array}{l}\text { Fluoresensi } \\
\text { tua }\end{array}$ & Biru \\
\hline 3 & 0,49 & & & \\
\hline
\end{tabular}


Masing-masing pita (pita 1-3) dikerok, dilarutkan dengan $5 \mathrm{~mL}$ aseton. Ditimbang berat dari masing-masing subfraksi sehingga diperoleh berat SF IV $B_{1.1}(0,7 \mathrm{mg}), \mathrm{SF} \mathrm{B}_{1.2}$ $(0,6 \mathrm{mg})$, dan SF $\mathrm{B}_{1.3}(3,2 \mathrm{mg})$. Rendemen subfraksi dijelaskan pada Tabel 11.

Tabel 11. Rendemen Subfraksi KLT Preparatif Kedua Terhadap Subfraksi KLT Preparatif Pertama

\begin{tabular}{lll}
\hline Subfraksi & Bobot Subfraksi & Rendemen Subfraksi \\
\hline SF IV B $_{1.1}$ & $0,7 \mathrm{mg}$ & $8,30 \%$ \\
SF IV B & $0,6 \mathrm{mg}$ & $7,14 \%$ \\
SF IV B & $3,2 \mathrm{mg}$ & $38,09 \%$ \\
\hline
\end{tabular}

Dipilih SF IV $\mathrm{B}_{1.3}$ berdasarkan pola bercak dari pita kemudian dilanjutkan pemantauan pola bercaknya dengan KLT menggunakan eluen n-heksan : etil asetat (8:2). Hasil kromatografi lapis tipis menunjukkan bahwa isolat yang diperoleh terdapat bercak tunggal berwarna biru terang pada Rf 0,49. Isolat kemudian kemurniannya diuji dengan KLT dua dimensi.

\section{Hasil Pengujian Kemurnian Isolat Menggunakan Kromatografi Lapis Tipis Dua Dimensi}

Isolat SF IV $\mathrm{B}_{1.3}$ dimurnikan dengan KLT dua dimensi. Pengembangan pertama menggunakan perbandingan eluen n-heksan : etil asetat $(7,5: 2,5)$. Setelah jenuh, KLT dibalik arahnya untuk pengembangan kedua, dilakukan penurunan kepolaran menggunakan eluen kloroform : n-heksan (5:5), masing-masing eluen dilarutkan dalam 4 $\mathrm{mL}$ fase gerak. Kromatogram menunjukkan bahwa isolat murni yang diperoleh merupakan senyawa murni dengan bercak tunggal berwarna biru terang pada sinar UV $\lambda 366 \mathrm{~nm}$ yang selanjutnya akan diuji aktivitas antibakterinya.

\section{Hasil Karakterisasi Senyawa Aktif Melalui Spektrofotometri UV-vis, Spektroskopi IR, dan Spektrometri Massa}

Karakterisasi isolat murni dilakukan melalui spektrofotometri ultraviolet-visible (uv-vis), spektroskopi inframerah (IR), dan spektrometri massa (MS).

\section{Spektrometri Ultraviolet-Visible}

Karakterisasi isolat SF IV B 1.3 $_{1.3}$ dilakukan dengan spektrometri UV-vis. Isolat diukur dari panjang gelombang 200-400 nm dengan menggunakan pelarut metanol pada konsentrasi $1.000 \mathrm{ppm}$. Hasil dari spektrometri uv-vis menunjukkan bahwa pita I (339,7 $\mathrm{nm})$ menghasilkan absorbansi maksimum pada 0,017 dan pita II $(202,90 \mathrm{~nm})$ dengan absorbansi 1,578. Hal ini menunjukkan bahwa spektrum senyawa aromatik mengandung transisi $\pi \rightarrow \pi^{*}$ (termasuk pita B dan pita K) pada $\lambda$ maks $202,9 \mathrm{~nm}$ dan muncul pita $\mathrm{R}$ pada $\lambda 339,7 \mathrm{~nm}$ dengan transisi $\mathrm{n} \rightarrow \pi^{*}$. SF IV $\mathrm{B}_{1.3}$ diduga mempunyai senyawa benzen dengan sistem terkonjugasi yang terikat oleh suatu ausokrom.

\section{Spektroskopi Inframerah}

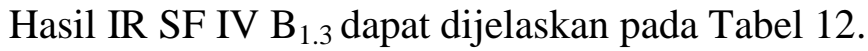


Tabel 12. Hasil Pengukuran Spektroskopi Inframerah

\begin{tabular}{cccc}
\hline $\begin{array}{c}\text { Bilangan } \\
\text { Gelombang }\left(\mathrm{cm}^{-1}\right)\end{array}$ & Intensitas & $\begin{array}{c}\text { Bentuk } \\
\text { puncak }\end{array}$ & Interpretasi \\
\hline 3745,6 & Lemah & Lebar & Regang O-H, H tidak terikat \\
3435,3 & Lemah & Lebar & Regang O-H, H terikat \\
2931,0 & Sedang & Tajam & Regang C-H alifatis \\
1492,6 & Sedang & Tajam & Regang C-C aromatis \\
1081,0 & Kuat & Tajam & Regang C-O \\
824,5 & Kuat & Tajam & Lentur oop C-H keluar bidang \\
& & & (aromatis) \\
\hline
\end{tabular}

Spektrum IR isolat SF IV $\mathrm{B}_{1.3}$ menunjukkan adanya regang $\mathrm{O}-\mathrm{H}$ yang tidak terikat $\mathrm{H}$ secara langsung pada $3745,6 \mathrm{~cm}^{-1}$, yang ditandai dengan intensitas lemah dan lebar. Pita serapan pada $3435,3 \mathrm{~cm}^{-1}$ menunjukkan adanya regang $\mathrm{O}-\mathrm{H}$ dengan $\mathrm{H}$ terikat langsung, ditandai dengan intensitas lemah dan lebar. Pita serapan pada $2931,0 \mathrm{~cm}^{-1}$ menunjukkan adanya regang C-H alifatis dengan intensitas sedang dan tajam. Pita serapan pada 1492,6 $\mathrm{cm}^{-1}$ menunjukkan adanya regang $\mathrm{C}-\mathrm{C}$ aromatis dengan intensitas sedang dan tajam. Pita serapan pada $1081,0 \mathrm{~cm}^{-1}$ menunjukkan adanya regang $\mathrm{C}-\mathrm{O}$ dengan intensitas kuat dan tajam. Pita serapan pada $824,5 \mathrm{~cm}^{-1}$ menunjukkan adanya lentur $\mathrm{C}-\mathrm{H}$ keluar bidang pada senyawa aromatis dengan intensitas kuat dan tajam.

\section{Spektrometri Massa}

Spektrum massa isolat SF IV $\mathrm{B}_{1.3}$ menunjukkan puncak senyawa dengan kelimpahan relatif $100 \%$ memiliki $\mathrm{m} / \mathrm{z}$ 324,8885. Berdasarkan pustaka atau literatur yang disesuaikan dengan berat molekul (Nara Institute of Science and Technology, 2007) dan pendekatan famili, diidentifikasi senyawa glabranin dengan rumus molekul $\mathrm{C}_{20} \mathrm{H}_{20} \mathrm{O}_{4}$. Struktur molekul Glabranin dijelaskan pada Gambar 1.

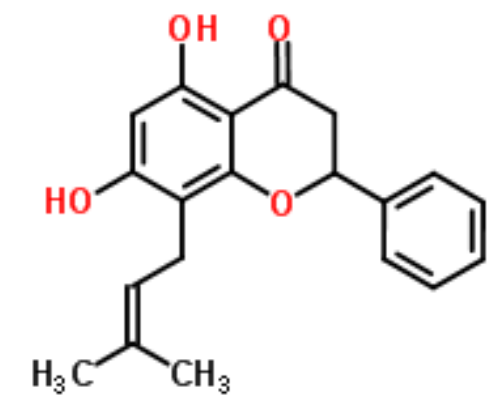

Gambar 1. Struktur molekul glabranin (Royal Society of Chemistry, 2014)

Dilihat dari spektrum MS, terdapat puncak-puncak yang spesifik pada $\mathrm{m} / \mathrm{z}$ antara lain 91,$2310 ; 254,6860 ; 310,8387 ; 324,8885 ; 338,9402$; dan 352,9806. Hasil spektrum MS dijelaskan pada Tabel 13. 
Tabel 13. Hasil Pengukuran Spektrometri Massa

\begin{tabular}{cccc}
\hline $\mathrm{m} / \mathrm{z}$ & $\begin{array}{c}\text { Kelimpahan relatif } \\
(\%)\end{array}$ & $\begin{array}{c}\text { Interpretasi } \\
\text { fragmentasi }\end{array}$ & $\begin{array}{c}\text { Rumus } \\
\text { molekul }\end{array}$ \\
\hline 352,9806 & Mendekati $20 \%$ & {$\left[\mathrm{M}^{+}\right]$} & $\mathrm{C}_{22} \mathrm{H}_{24} \mathrm{O}_{4}$ \\
338,9402 & Mendekati $85 \%$ & {$\left[\mathrm{M}^{+}-\mathrm{CH}_{2}\right]$} & $\mathrm{C}_{21} \mathrm{H}_{22} \mathrm{O}_{4}$ \\
324,8885 & $100 \%$ & {$\left[\mathrm{M}^{+}-\mathrm{C}_{2} \mathrm{H}_{4}\right]$} & $\mathrm{C}_{20} \mathrm{H}_{20} \mathrm{O}_{4}$ \\
310,8387 & $90 \%$ & {$\left[\mathrm{M}^{+}-\mathrm{C}_{3} \mathrm{H}_{6}\right]$} & $\mathrm{C}_{19} \mathrm{H}_{18} \mathrm{O}_{4}$ \\
254,6860 & $25 \%$ & {$\left[\mathrm{M}^{+}-\mathrm{C}_{4} \mathrm{H}_{8}\right]$} & $\mathrm{C}_{18} \mathrm{H}_{16} \mathrm{O}_{4}$ \\
91,2310 & $10 \%$ & {$\left[\mathrm{M}^{+}-\mathrm{C}_{15} \mathrm{H}_{17} \mathrm{O}_{4}\right]$} & $\mathrm{C}_{7} \mathrm{H}_{7}$ \\
\hline
\end{tabular}

\section{Kesimpulan}

Berdasarkan penelitian yang telah dilakukan, diperoleh kesimpulan sebagai berikut:

1. Fraksi etil asetat sebagai fraksi teraktif memiliki aktivitas antibakteri pada konsentrasi $20 \%$ sebesar 19,5 mm dan konsentrasi $30 \%$ sebesar 22,3 mm.

2. Karakterisasi isolat SF IV $\mathrm{B}_{1.3}$ dari fraksi etil asetat dengan spektometri $U V$-Vis menunjukkan serapan pada $\lambda$ maks $202,9 \mathrm{~nm}$ dan $\lambda 339,7 \mathrm{~nm}$; hasil spektroskopi IR menunjukkan gugus fungsi $\mathrm{O}-\mathrm{H}, \mathrm{C}-\mathrm{H}$ alifatis, $\mathrm{C}=\mathrm{C}$ aromatis, $\mathrm{C}=\mathrm{O}$ dan $\mathrm{C}-\mathrm{H}$ aromatis; dan hasil spektometri massa menunjukkan senyawa dengan $\mathrm{m} / \mathrm{z} 352,9806$ diduga dimetoksi glabranin $\left(\mathrm{C}_{22} \mathrm{H}_{24} \mathrm{O}_{4}\right)$ yang memiliki aktivitas antibakteri.

\section{Ucapan Terima Kasih}

Penulis mengucapkan terima kasih atas bantuan biaya penelitian melalui Beasiswa Pascasarjana (Beasiswa Unggulan 2012) a.n. Viriyanata Wijaya dari Ditjen DIKTI (Direktorat Jenderal Pendidikan Tinggi) Kementerian Pendidikan dan Kebudayaan RI.

\section{DAFTAR PUSTAKA}

Foster TJ, McDevitt D (1994) Surface-associated proteins of Staphylococcus aureus: their possible role in virulence. FEMS Microbiol Lett 118: hal 199-206

Lowy FD. 1998. Is Staphylococcus aureus an intracellular pathogen. Trends Microbiol 8: hal 341-344

Maring, Hermas R. 2006. Punan: masyarakat di pinggir negara. Melalui (rafflesia.wwf.or.id/library/attachment/pdf/Feature_Jr3.pdf) [diakses tanggal $6 \mathrm{Mei}$ 2014]

Nara Institute of Science and Technology, 2007. KNApSAck Metabolite InformationGlabranin. Melalui (http://kanaya.naist.jp/knapsack jsp /information.jsp) [diakses tanggal 25 April 2014]

Projan SJ, Novick RP. 1997. The molecular basis of pathogenicity. In: Crossley KB, Archer GL, eds. The Staphylococci in Human Diseases. Churchill Livingston, London, hal 55-81

Royal Society of Chemistry, 2014. Chem Spider-Glabranin. Melalui (http:// http://www.chemspider.com) [diakses tanggal 30 April 2014]

Waldvogel FA. 1990. Staphylococcus aureus (including toxic shock syndrome), In: Mandell GL, Douglas RG, Bennett JE (eds.). Principles and Practice of Infectious Disease, 3rded. Churchill Livingston, London. hal. 1489-1510

Yusuf, Razali. 2005. Keanekaragaman dan Potensi Jenis Tumbuhan Hutan Sekunder di Kuala Ran, Kabupaten Bulungan, Kalimantan Timur. BioSMART Volume 7, Nomor 1 April 2005, hal: 37-43 ISSN: 1411-321X 